\title{
Ontogenic development of kidney, thymus and spleen and phenotypic expression of CD3 and CD4 receptors on the lymphocytes of cobia (Rachycentroncanadum)
}

\author{
MARTA C. KLOSTERHOFF ${ }^{1}$, JOABER PEREIRA JÚNIOR ${ }^{2}$, RICARDO V. RODRIGUES ${ }^{3}$, \\ EMELINE P. GUSMÃO ${ }^{1}$, LUÍS A. SAMPAIO ${ }^{3}$, MARCELO B. TESSER ${ }^{3}$ and LUIS A. ROMANO ${ }^{1}$ \\ ${ }^{1}$ Laboratório de Imunologia e Patologia de Organismos Aquáticos, Universidade Federal do Rio \\ Grande/FURG, Rua do Hotel, 2, Bairro Cassino, 96210-030 Rio Grande, RS, Brasil \\ ${ }^{2}$ Laboratório de Parasitologia de Organismos Aquáticos, Universidade Federal do Rio Grande/ \\ FURG, Rua do Hotel, 2, Bairro Cassino, 96210-030 Rio Grande, RS, Brasil \\ ${ }^{3}$ Laboratório de Piscicultura Estuarina e Marinha, Universidade Federal do Rio Grande/ \\ FURG, Rua do Hotel, 2, Bairro Cassino, 96210-030 Rio Grande, RS, Brasil
}

Manuscript received on January 23, 2015; accepted for publication on February 17, 2015

\begin{abstract}
In the present study was evaluated the ontogenic of immunocompetent organs of cobia up to 53 days after hatching (dah) through histology and immunohistochemistry techniques. The kidney was the first lymphohematopoietic organ to appear, at 1 dah, followed by the spleen at 5 dah and the thymus at 7 dah. The first CD3 receptors on the lymphocytes were observed in $27 \%$ of the thymic tissue at 7 dah and in $99 \%$ at 53 dah. The phenotypic expression of CD3 receptors was registered in $10 \%$ of the kidney at 8 dah and in $32 \%$ at 53 dah. CD4 receptors were observed in $5 \%$ and $63 \%$ of the thymic area at 7 and 53 dah, respectively. In the kidney, T4 lymphocytes were first observed at 13 dah in $9 \%$ of the organ and in $28 \%$ at 53 dah, defining the functional development of the specific system associated with immunological memory capacity.
\end{abstract}

Key words: cobia, immune system, ontogeny, immunohistochemistry, lymphoid organs.

\section{INTRODUCTION}

The cobia Rachycentron canadum (Rachycentridae) is a carnivorous fish widely distributed in tropical and subtropical waters in the Pacific, Atlantic and Indian oceans, except for in the eastern Pacific.

This species has many favorable characteristics for aquaculture, especially its high growth rate, adaptability to confinement, acceptance of dry diets, ease of spawning in captivity (Chou et al. 2001) and excellent flesh characteristics (Craig et

Correspondence to: Luis Alberto Romano

E-mail: luisalbertoromano@gmail.com al. 2006, Liao and Leaño 2007, Liao et al. 2004). However, cobia is a recent addition to aquaculture species, and very little is known regarding biological concerns, such as the physiology of the immune system; the cells, tissues and organs that participate in the immune response; and the ontogeny of this system (Holt et al. 2007).

The immune system of teleost is divided into the innate or nonspecific immune system and the adaptive or specific immune system. The nonspecific immune system is antigen- independent and has no immunological memory. The specific or adaptive immune response is antigen-dependent, 
generating a specific response against one antigen, resulting in immunological memory.

To establish the ontogeny of the immune system of fish, it is necessary to analyze the lymphoid organs, thymus, kidney and spleen through histology. The thymus in teleost fishes shows structural and functional similarity to the thymus of mammals and is the key organ in the differentiation and maturation of the $\mathrm{T}$ lymphoid lineage (Zapata et al. 1996). The kidney, in addition to the thymus, plays an important role in the functioning of the immune system of teleost fishes. The head kidney is responsible for lymphohematopoiesis (Zapata et al. 1996). The spleen consists of splenic sinusoids, surrounded by lymphoid cells that contain red blood cells. Its functional unit is the ellipsoid corpuscle, composed a capillary surrounded by melanomacrophages, which is apparently involved in the elimination of the antigen-antibody complex and the destruction of old blood cells (Danneving and Landsverk 1995).

The aim of this study was to evaluate the ontogeny of immune system organs of cobia through conventional histology techniques and the phenotypic expression of the CD3 and CD4 lymphoid receptors through immunohistochemistry. Thus, the age at which the immune system is developed and is apparently functional, as indicated by the presence of a mixed lymphoid population and immunologic memory would be able to be established.

\section{MATERIALS AND METHODS}

The Ethics Committee approved this research for Animal Research of the Universidade Federal do Rio Grande (23116.00197/2014-99).

OBTAINING AND MAINTENANCE OF LARVAE AND JUVENILES IN LABORATORY

Cobia larvae were produced at Aqualider Inc., Pernambuco, Brazil, according to the protocol established for the species (Benetti et al. 2008).
Newly hatched larvae were stocked in a fiberglass tank with $12,000 \mathrm{~L}$ at a density of 15 larvae per liter. The tanks were kept in a flowthrough system with a water exchange rate of $500 \%$ per day. The water temperature was kept at $29.5 \pm 0.3{ }^{\circ} \mathrm{C}$ with a salinity of $35 \mathrm{ppt}$. The oxygen concentration and $\mathrm{pH}$ were $6.5 \mathrm{mg} \mathrm{L}^{-1}$ and 8.09, respectively.

The enrichment of rotifers and Artemia sp. was performed with 85\% Algamac 3050, 10\% Algamac ARA, and 5\% Algamac Astaxanthin. During the enrichment period, the concentration of rotifers was maintained between $500-600 \operatorname{rot} \mathrm{mL}^{-1}$, and 0.6 $\mathrm{g} \mathrm{L}^{-1}$ of enrichment solution was used for every 1,000,000 rotifers for $6 \mathrm{~h}$. Artemia sp. were kept at a concentration of 250-300 art $\mathrm{mL}^{-1}$, and $0.6 \mathrm{~g}$ $\mathrm{L}^{-1}$ of enrichment solution was offered for every 1,000,000 Artemia sp. for $24 \mathrm{~h}$.

The first feeding was offered 2 days after hatching (dah), and it was composed only of enriched rotifers (Brachionus plicatilis) at a density of 5 rotifers $\mathrm{mL}^{-1}$ until 6 dah. At 7 and 8 dah, the larvae were fed with enriched rotifers and newly hatched Artemia sp. nauplii. During the entire period of rotifer administration, the microalgae Nannochloropsis oculatta was inoculated at a density of $15 \times 10^{4}$ cells $\mathrm{mL}^{-1}$. Next, the larvae were exclusively fed with Artemia sp. nauplii 9 dah, and from 11 to 15 dah, larvae were fed only with enriched Artemia sp. From 16 to 27 dah, enriched Artemia sp. and a commercial diet (NRD, Inve, USA - 59\% protein, $16 \%$ lipids) were offered every 4 hours. Finally, all fish were weaned to the commercial diet 28 dah.

HISTOLOGICAL AND MORPHOMETRIC ANALYSIS

Larvae and juveniles ( 0 to $15,17,19,21,23,25,28$, 49 and 53 dah) (n per day $=15)$, were euthanized with 50 ppm Aqui-S ${ }^{\circledR}$. To perform the histological analysis of the kidney, thymus and spleen and subsequent morphometric analysis, the animals were fixed in $20 \%$ buffered formaldehyde. Then the samples were dehydrated in graded ethanol series, 
incorporated with Paraplast Plus (Sigma Aldrich, Brazil) and cut in longitudinal sections (3 -5 $\mu \mathrm{m}$ thick). The resulting sections were subsequently stained with hematoxylin, eosin and PAS. For morphometric analysis of the thymus and head kidney, longitudinal sections of about $0.5 \mathrm{~mm}$ in thickness were prepared. The area of these organs was measured using the Weibel graticules, with lines, according to Weibel (1979).

\section{IMMUNOHISTOCHEMISTRY}

In the immunohistochemistry of the kidney and thymus the same animals processed for histological analyses were used. The ABC peroxidase method was applied (Vectastain Elite ABC Kit, Canada), as described by Hsu et al. (1981). The sections were incubated with a human monoclonal antibody, anti CD3 and anti CD4 (Dako, Argentina), previously tested for fish in Xiphophorus helleri and Danio rerio (Romano et al. 2004, Batista et al. 2014). The evaluation of CD3 and CD4 receptors was performed by quantitative analysis of the phenotypic percentage by $\mathrm{mm}^{2}$ of tissue. The expression of these receptors was quantified using Bioscan OPTIMAS 6.1 software (Romano et al. 1996, Batista et al. 2014).

\section{RESULTS}

\section{HistOLOGICAL ANALYSIS}

The lymphoid organs appear in the following sequence: anterior kidney, spleen and thymus. The kidney is anatomically located in the retroperitoneal space between the parietal peritoneum and spine. The kidney was observed at 1 dah with only two renal tubules, and lymphoid cells were observed after 2 dah. In the head kidney, the hematopoietic tissue mass increased progressively with age. At 4 dah, the lymphohemopoietic cell population and the number of renal tubules increased, and the first glomerulus was also observed. Between 5 and 8 dah, the volume of lymphohemopoietic tissue increased.
After 9 dah, the size of the kidney augmented and renal structures became more evident. By 49 and 53 dah, glomeruli and renal tubules were distributed uniformly and were surrounded by a large number of lymphohemopoietic cells (Fig. 1).

The thymus is a bilateral organ that consists of a uniform mass of lymphoid cells surrounded by a thin capsule of connective tissue and is linked to the pharyngeal epithelium located in the dorsal region of each branchial cavity. The thymus can be observed at 7 dah as a small population of lymphocytes that increases with time. After 15 dah, the lymphoid cells and the pharyngeal epithelium became evident. At 23 dah, the thymus appears to be divided into three lobes, and between 49 and 53 dah, it in volves a large portion of the pharyngeal epithelium. At 53 dah, Hassal-like corpuscles, which are similar to the corresponding structures in mammals and humans, are found among the lymphocytes (Fig. 2).

The spleen was first observed at 5 da has a few splenic cells in the peritoneal cavity adjacent to the intestine wall and next to the pancreatic tissue. At 10 dah, there was an increase in the number of splenic cells. After 53 dah, the ellipsoid corpuscle was observed, composed of capillaries surrounded by melanomacrophage PAS positive (Fig. 3).

\section{MORPHOMETRIC ANALYSIS}

The mean length of the larvae and juveniles was $3.8 \pm 0.04 \mathrm{~mm}$ at $1 \mathrm{dah}$, with exponential growth throughout the period studied, before reaching the final length of $154 \pm 4.6$ at 53 dah.

The kidney, spleen and thymus showed a gradual increase in size relative to the total length of larvae and juveniles.

The kidney had a length (L) of $0.11 \mathrm{~mm}$ and total area (TA) of $0.11 \mathrm{~mm}^{2} 1$ dah $(3.8 \pm 0.04 \mathrm{~mm})$, $\mathrm{a} \mathrm{L}=2.6 \mathrm{~mm}$ and $\mathrm{TA}=1.18 \mathrm{~mm}^{2}$ at $12 \mathrm{dah}(8.3 \pm$ $0.4 \mathrm{~mm})$, and $\mathrm{L}=3.3 \mathrm{~mm}$ and $\mathrm{TA}=12.3 \mathrm{~mm}^{2} 53$ dah (154 $\pm 4.6 \mathrm{~mm})$ (Fig. 4). 


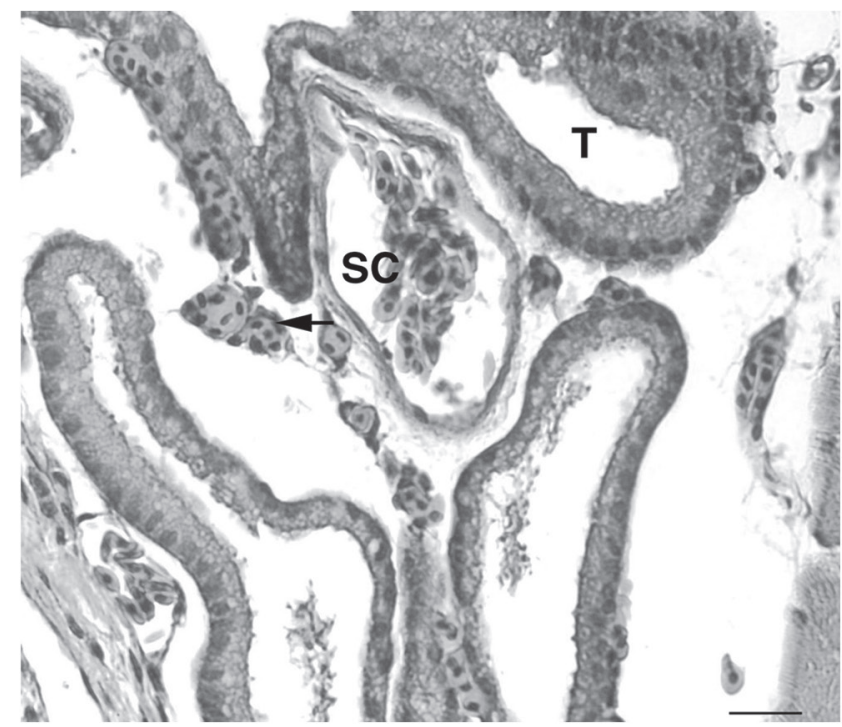

(a)

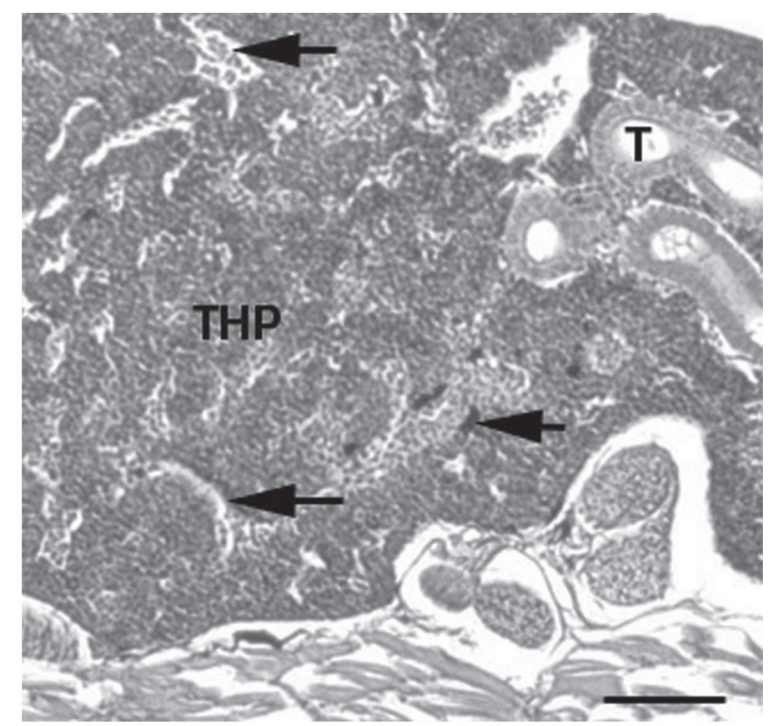

(b)

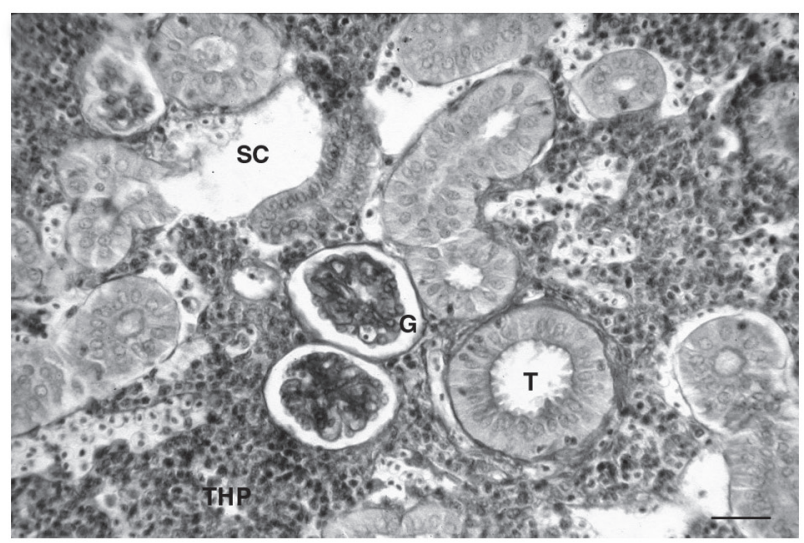

(c)

Figure 1 - a Kidney of larvae 2 dah, with tubules (T), capillary sinusoids (SC) and erythrocytes (arrow). Lymphohematopoietic cells were not observed. (Bar= $200 \mu \mathrm{m}$ ). Section was stained with Haematoxylin-Eosin; b Kidney at 19 dah with tubules (T), hematopoietic tissue (THP), capillary sinusoids (long arrow) and melanomacrophages (short arrow) (Bar=100 $\mu \mathrm{m})$. Section was stained with Haematoxylin-Eosin; c Kidney of juvenile at 53 dah with a tubule (T), glomeruli (G), capillary sinusoids (SC) and abundant lymphohematopoietic tissue (THP) (Bar= $100 \mu \mathrm{m})$. Section was stained with Haematoxylin-Eosin.

The thymus measured $\mathrm{L}=0.14 \mathrm{~mm}$ and $\mathrm{TA}=$ $0.17 \mathrm{~mm}^{2}$ at $7 \mathrm{dah}(5.4 \pm 0.20 \mathrm{~mm}), \mathrm{L}=0.32 \mathrm{~mm}$ and $\mathrm{TA}=0.28 \mathrm{~mm}^{2}$ at $21 \mathrm{dah}(29.8 \pm 2.1 \mathrm{~mm})$ and $\mathrm{L}=0.49 \mathrm{~mm}$ and $\mathrm{TA}=1.68 \mathrm{~mm}^{2}$ at $53 \mathrm{dah}(154 \pm$ $4.6 \mathrm{~mm}$ ) (Fig. 5).

At 5 dah, the spleen was $(4.8 \pm 0.2 \mathrm{~mm}) \mathrm{L}=0.2$ $\mathrm{mm}$ and $\mathrm{TA}=0.17 \mathrm{~mm}^{2}$, and it gradually increased in size until 53 dah $(154 \pm 4.6 \mathrm{~mm})$, reaching $\mathrm{L}=$ $1.54 \mathrm{~mm}$ and TA $=16.5 \mathrm{~mm}^{2}$ (Fig. 6).

\section{ANALYSIS OF THE PHENOTYPIC EXPRESSION OF CD3 AND CD4}

The phenotypic expressions of CD3 and CD4 lymphoid receptors increased with the age of larvae and juveniles. In the thymus, the first CD3 receptors were observed at 7 dah $(5.4 \pm 0.2 \mathrm{~mm})$, occupying $27 \% / \mathrm{mm}^{2}$ of thymic tissue. At 53 dah they occupied $99 \% / \mathrm{mm}^{2}$ of the thymic tissue (154 $\pm 4.6 \mathrm{~mm}$ ). The phenotypic expression of the CD3 


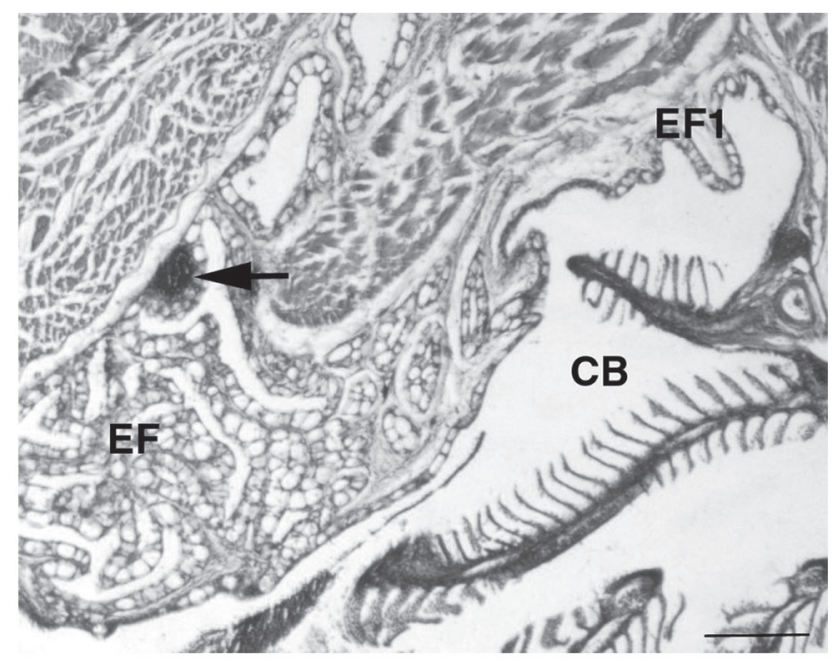

(a)

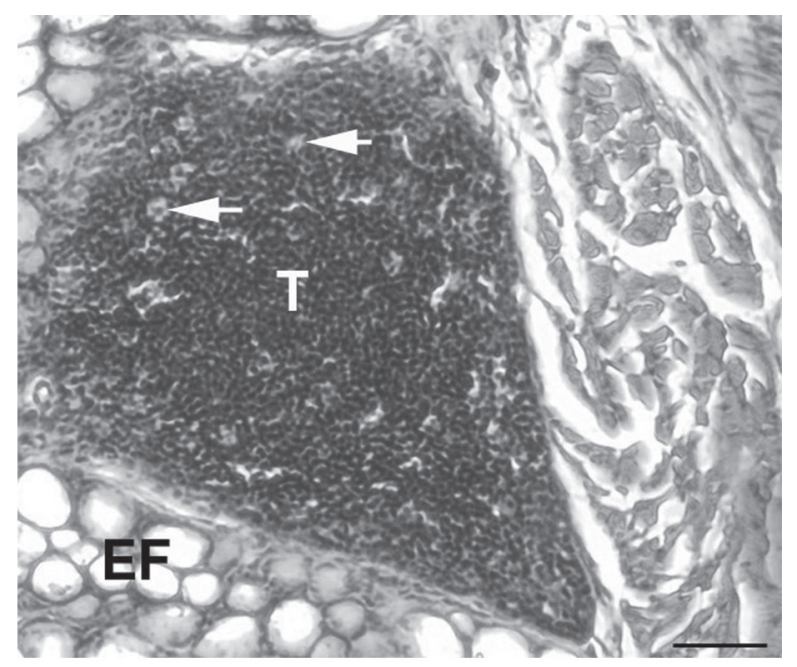

(b)

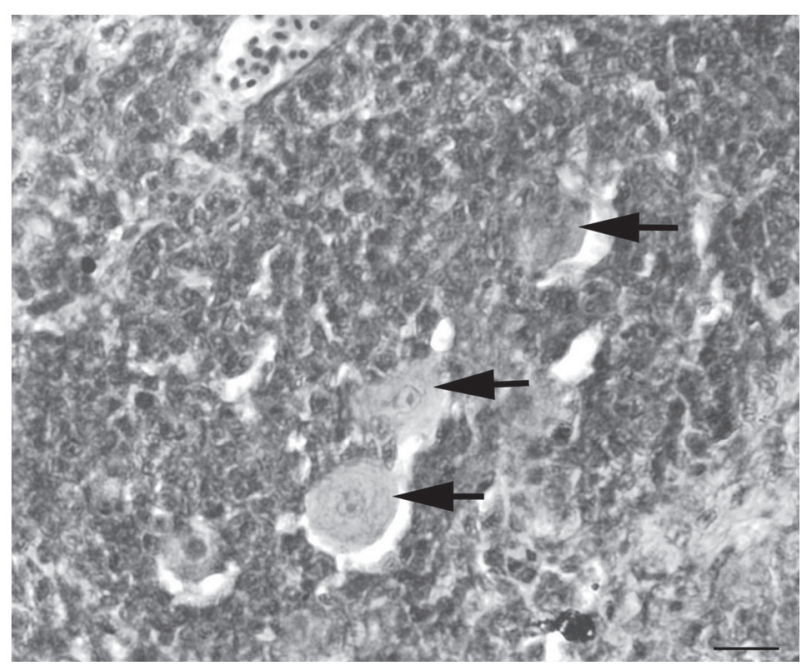

(c)

Figure 2 - a Thymus at 3 dah (arrow), involved with the pharyngeal epithelium (EF), which originates in the gill cavity $(\mathrm{CB})(\mathrm{Bar}=$ $200 \mu \mathrm{m})$. Section was stained with Haematoxylin-Eosin; b Thymus (T) at 28 dah with the pharyngeal epithelium (EF) and Hassallike corpuscles (arrow) $(\mathrm{Bar}=100 \mu \mathrm{m})$. Section was stained with Haematoxylin- Eosin; c Thymus at 53 dah, with lymphocytes, capillaries $(\mathrm{C})$ and Hassal-like corpuscles (arrow), $(\mathrm{Bar}=50 \mu \mathrm{m})$. Section was stained with Haematoxylin-Eosin.

receptors in the kidney started at 8 dah $(6.5 \pm 0.1$ $\mathrm{mm})$ in $10 \% / \mathrm{mm}^{2}$ of the kidney tissue and reached $32 \% / \mathrm{mm}^{2}$ of the kidney tissue at 53 dah (Fig. $7 \mathrm{a}$ ).

The phenotypic expression of CD4 lymphoid receptors (T4 lymphocytes) started in the thymus at 7 dah, with $5 \% / \mathrm{mm}^{2}$ of thymic tissue. At 53 dah they occupied $63 \% / \mathrm{mm}^{2}$ of thymic tissue. In the kidney, the T4 lymphocyte population was first registered at 13 dah $(12.4 \pm 0.7 \mathrm{~mm})$ with $9 \% / \mathrm{mm}^{2}$ presented $28 \% / \mathrm{mm}^{2}$ at 53 dah (Fig. 7 b).

\section{DISCUSSION}

The immune system of teleost fishes is similar to that in mammals with respect to its cells and molecules, but the morphology of this system is different regarding the organs and the functions 


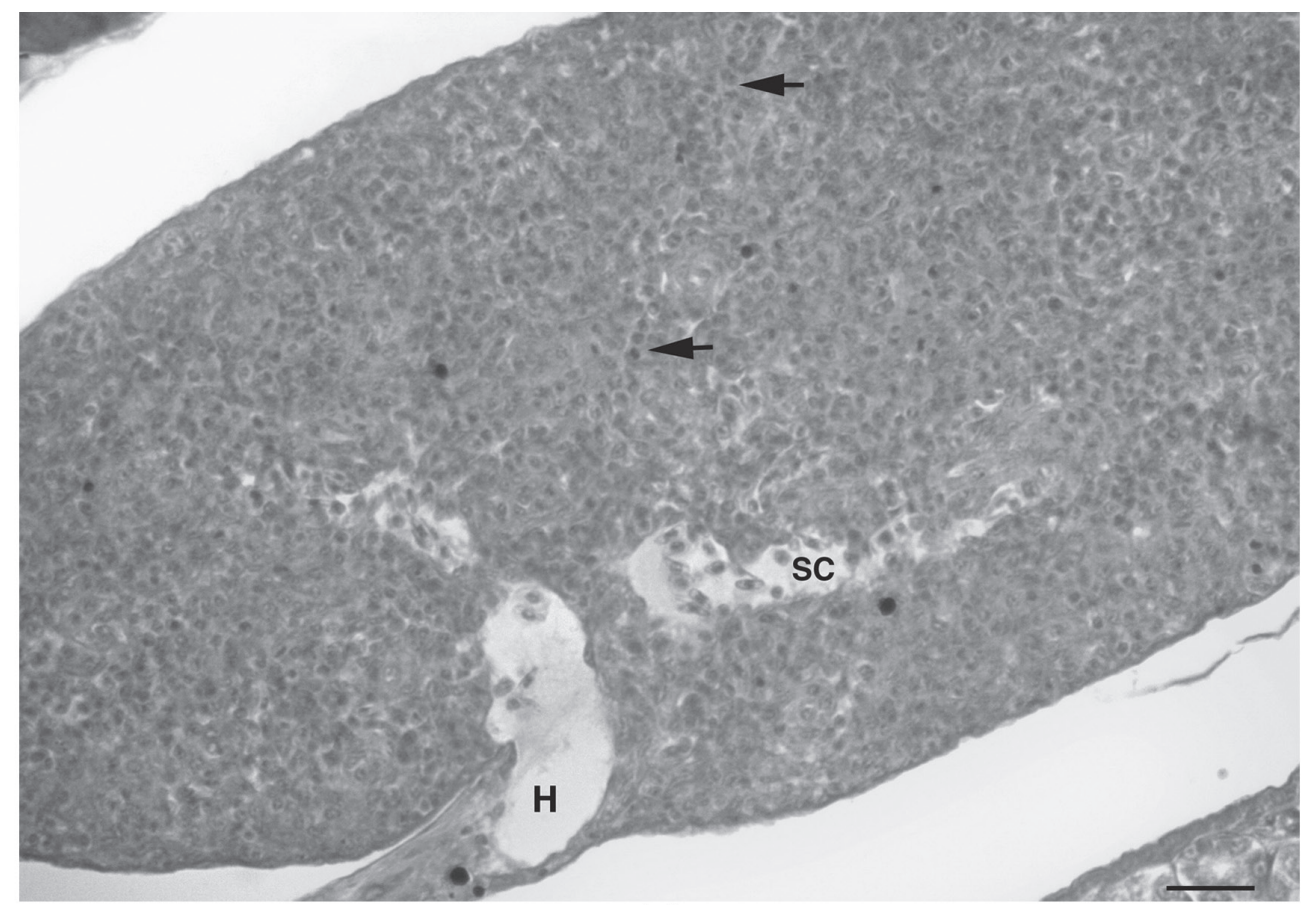

(a)

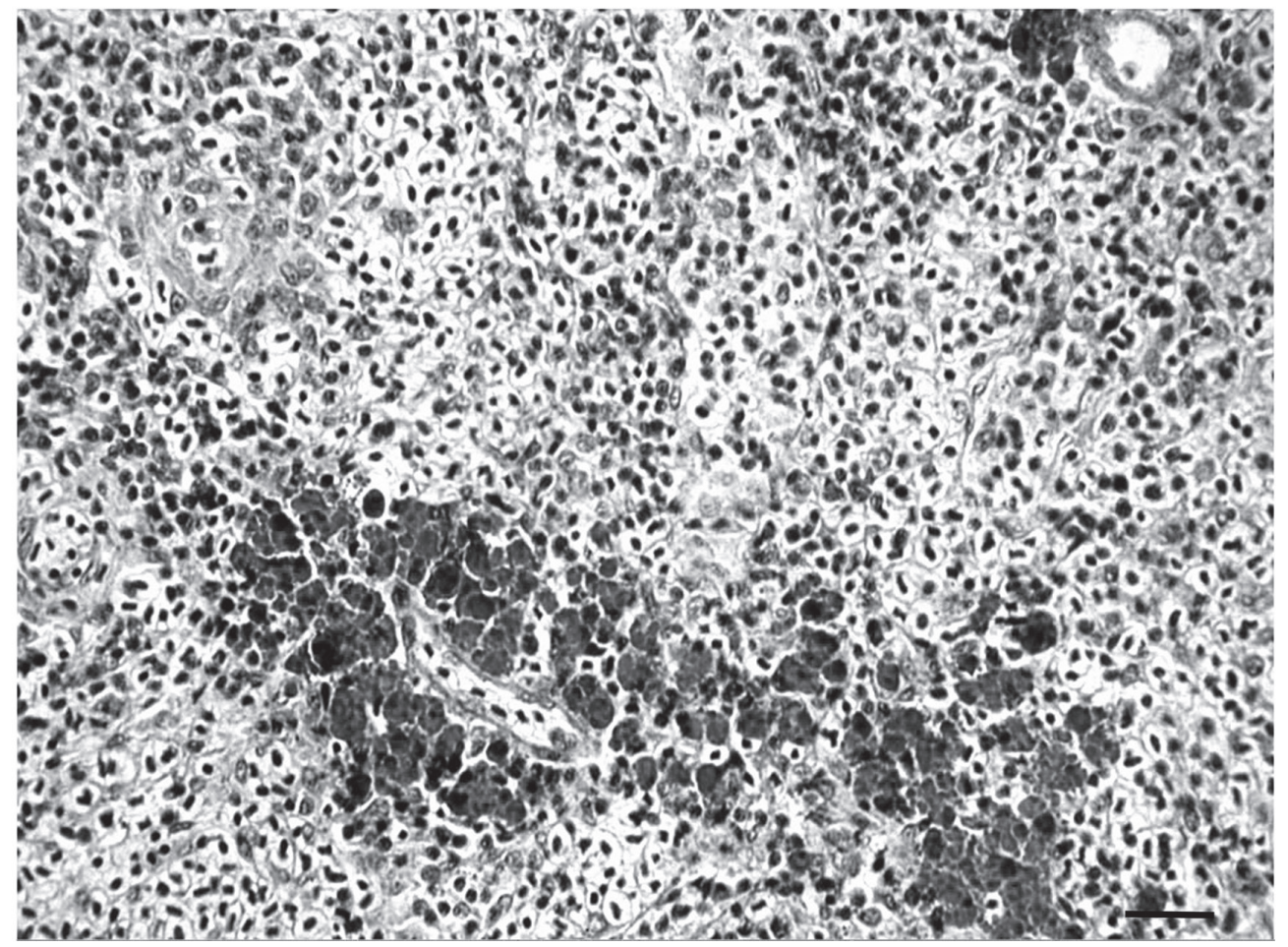

(b)

Figure 3 - a Spleen at 19 dah with two networks, connective tissue and capillary sinusoids (SC). The cells filling up the spaces within the networks (arrows) (Bar= $200 \mu \mathrm{m})$. Section was stained with Haematoxylin-Eosin; b Spleen at 53 with increase in the number of splenic cells (SC) and the ellipsoid corpuscle, composed of capillaries surrounded by melanomacrophage PAS positive (arrow) (Bar= 100 $\mu \mathrm{m})$. Section was stained with Haematoxylin-Eosin. 

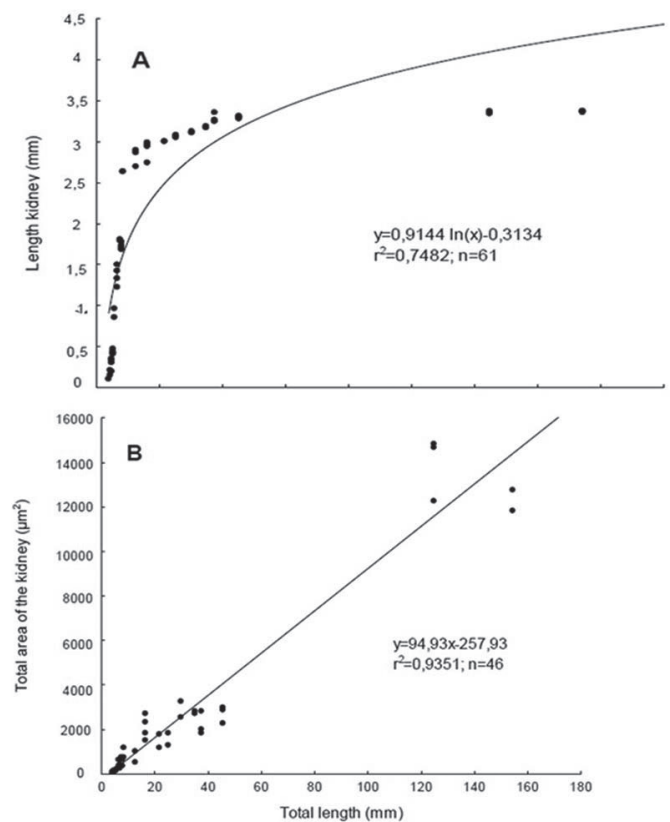

Figure 4 - Growth of kidney in larvae and juvenile cobia Rachycentron canadum. (a) Length of kidney. (b) Area of kidney.
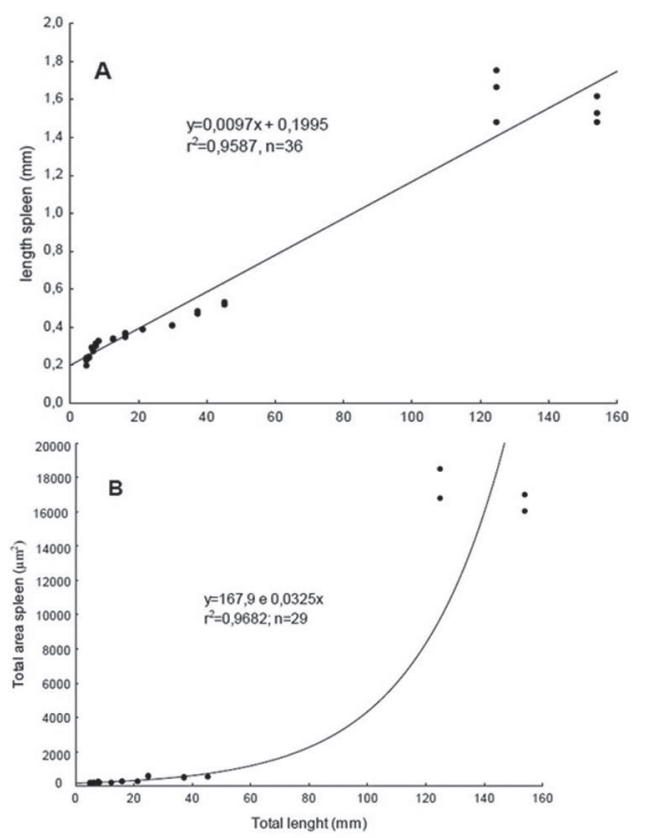

Figure 6 - Growth of the spleen of larvae and juvenile cobia Rachycentron canadum. (a) Length of spleen. (b) Area of spleen.

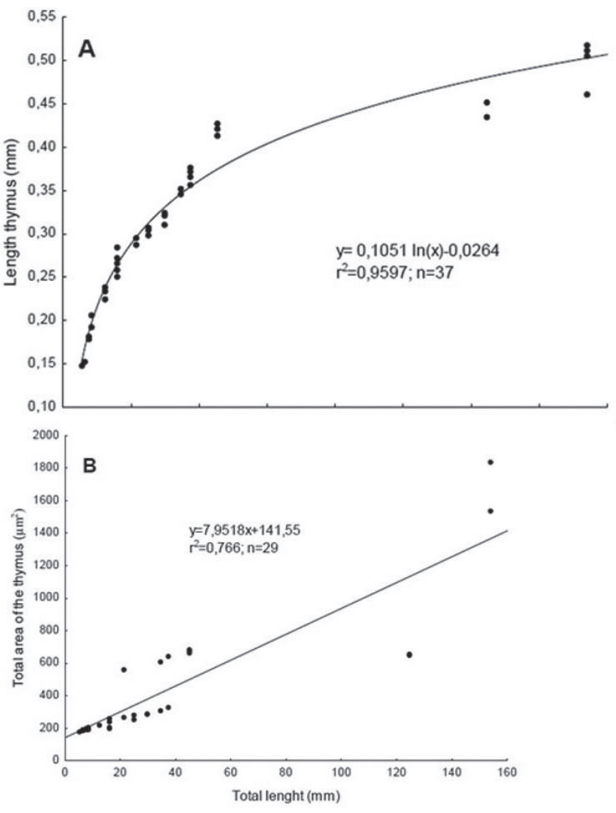

Figure 5 - Growth of thymus in larvae and juvenile cobia Rachycentron canadum. (a) Length of thymus. (b) Area of thymus.
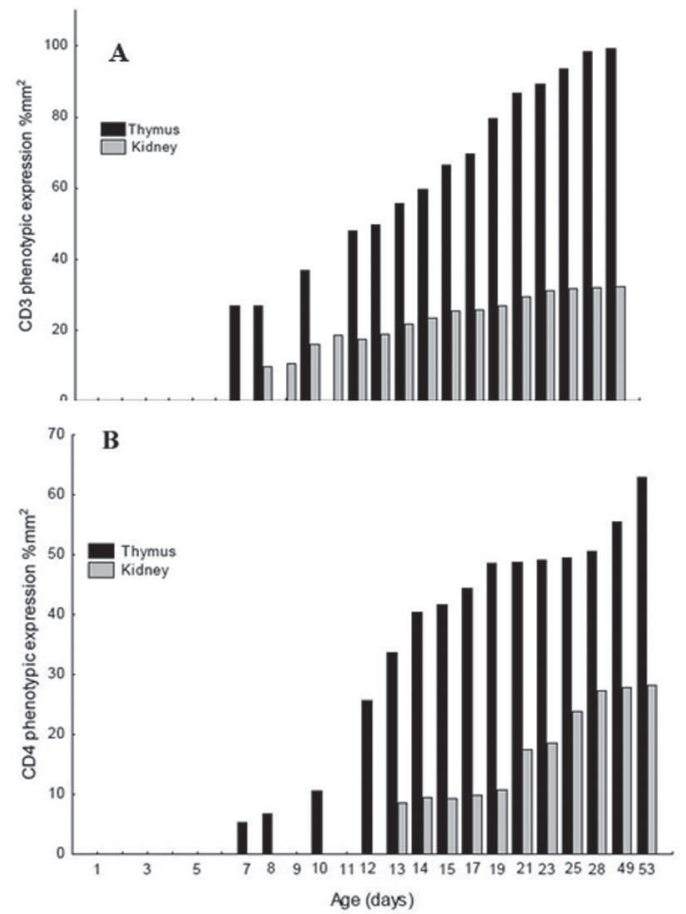

Figure 7 - Phenotypic expression of CD3 (a) and CD4 (b) in lymphocytes presents in the thymus and kidney of cobia Rachycentron canadum. 
they perform. A crucial difference between the systems in fish and that in comparison to that of mammals, is the absence of bone marrow in fish. Hematopoiesis occurs in the anterior portion of the kidney, which serves as an important lymphoid organ. In addition, lymph nodes, which have an important role in the immune response in mammals and humans, are also absent in fish (Zapata 1996).

Regarding lymphoid organs in fish, there are frequent reports of variations in the morphology of the thymus due to the absence of the corticomedullary junction. However, it is important to recognize that these differences mainly occur between species and are age-dependent. The location of the thymus has been reported in some species with different results (Bowden et al. 2005). The initial development of this organ in fish has been studied for several species of teleosts (Chantanachookhin 1991, Lam et al. 2002), such as the Atlantic halibut (Hippoglossus hippoglossus) where the thymic cells expand and the organ protrudes into the opercular cavity (Bowden et al. 2005). However, in other species, such as the common carp (Cyprinus carpio L.) and snook (Centropomus sp.), the predominant growth of the thymus is internal (Bowden et al. 2005). In this study, it was found that the thymus of cobia involves the pharyngeal epithelium located in the dorsal region of each branchial cavity.

Structures known as Hassall corpuscles are found in the medulla of the thymus of mammals and humans and are formed by lymphoepithelial cells connected by desmosomes. These cells, especially those in the center of the organ, can degenerate and die, leaving cellular debris that may calcify; however, their functions are unknown (Watanabe et al. 2005). Similar structures have been found in the thymus of cobia, in contrast to most studies, which describe an absence of Hassall structures in the thymus of teleost (Hibiya 1982), although others studies describe similar structures in fish (Bowden et al. 2005, Ellsaesser et al. 1988,
Chilmonczyk 1992). In rainbow trout, it is possible to observe thymic cells with an eosinophilic hyaline material deposit, which can be mistaken for Hassall corpuscles due to the fact that because these structures are strictly epithelial and are similar to onion layers (Palestro et al. 1998).

Studies of the human thymus have demonstrated that thymic cells produce proinsulin (Wentworth et al. 1992), and other researchers have shown that this proinsulin factor is produced in the Hassall corpuscle in the mouse thymus (Chentoufi et al. 2004). Considering the importance of this factor in the growth of all vertebrates, the observation of structures similar to those of Hassall corpuscles in the thymus of cobia could be related to the production of a proinsulin factor that would stimulate growth in this species, which presents a high growth rate (Liao and Leaño 2007).

In contrast to mammals and humans, the spleen of fish did not differentiate into white pulp and red pulp, which was also observed in the histological study of the spleen of Paralichthys olivaceus (Liu et al. 2004). The functional unit of this organ is the ellipsoid corpuscle, composed of capillaries surrounded by melanomacrophage and lymphoid tissue. The immune function of splenic lymphoid tissue has been controversial, mainly because of the differences found between species. Ontogenic studies on Atlantic salmon and rainbow trout suggest that the spleen is not essential for immune maturation, and lymphocytes from the thymus and head kidney perform many functions, whereas the spleen is still a rudimentary organ (Razquin et al. 1990).

Ontogeny is a sequence of molecular and cellular events ruled by time and space, leading to the development of a functional organism. According to research on ontogeny, it is clear that young fish rely on innate defense mechanisms during the first weeks/months of their development. Because of these findings, ontogeny studies are important for understanding the evolutionary paths and defense 
mechanisms of fish, against pathogens, at an early age (Rombout et al. 2005). It is also critical to study new species, such as cobia, because there are no reports in the literature concerning the development of its immune system; the present study is the first.

Compared to other teleost, the development of lymphoid organs in cobia was similar to that in other marine fish. The kidney in cobia was already present on the first day after hatching, with only a few renal tubules, which is the same age observed for Paralichthys olivaceus. In addition, the hematopoietic tissue mass increased gradually with the age of the fish (Liu et al. 2004).

The lymphoid organs of cobia appeared in the following sequence: anterior kidney, spleen and thymus, in accordance with those of other marine teleost, including flounder (Paralichthys olivaceus), sea bream (Sparus aurata), yellowtail (Seriola dumerili) and red sea bream (Pagrus major) (Chantanachookhin et al. 1991, Liu et al. 2004, Padros and Crespo 1996, Josefsson and Tatner 1993). However, in freshwater fish, such as salmon, trout and carp (Grace and Manning 1980, Bothamand Manning 1981), the thymus is the first lymphoid organ to appear in the development.

During the ontogeny of the immune system, it is possible to establish the moment when $\mathrm{T}$ lymphocytes repopulate the kidney. The lymphocytes that migrate from the head kidney to the thymus acquire specific T-cell receptors (thymus- dependent) (Nielsen and Esteve-Gassent 2006) and then return to the kidney and maintain the immune activities of B and T lymphocytes, as noted in this study through the analysis of the phenotypic expression of CD3 and CD4 receptors. From that moment, the thymus involutes in most species of fish at the time of sexual maturity (Fishelson 1995), although this involution can also be related to other factors, such as age, season, environmental stress and hormonal cycles (Press and Evensen 1999).

Morphological studies on the development of the immune systems of fish have shown that immune system mechanisms among teleost are very similar, showing differences only in the development of the adaptive immune system (Mulero et al. 2007). In this study, it was possible to establish when the specific immune system became functional from, based on the presence of T4 lymphocytes (CD4 receptors) in the thymus at 7 dah and in the kidney at 13 dah, which indicates the presence of immunological memory. The absence of $\mathrm{CD} 3$ and $\mathrm{CD} 4$ receptors in spleen lymphocytes is possibly caused by its predominant population of B lymphocytes and few T lymphocytes, which are insufficient for positive immunohistochemistry (Mishell and Dutton 1967).

Some authors report that due to the lack of appropriate cell markers for $\mathrm{T}$ lymphocytes in fish, the characteristics of T-cell populations have not yet been fully defined in teleost (Laing et al. 2006). The use of cross-reactivity is only possible because molecules present on $\mathrm{T}$ cell receptors of some species, are conserved during evolution (Romano et al. 2004, Conrad et al. 2007, Batista et al. 2014). This work has demonstrated the usefulness of classical histology and immunohistochemistry, which are accessible and technically simple tools, to evaluate the ontogenic development of the cobia and contribute o the cultivation and future research of this fish.

\section{ACKNOWLEDGMENTS}

The authors would like to thank the staff at the Marine Aquaculture Station. M. Klosterhoff and E. Gusmão are graduate students of Aquaculture at FURG and supported by Coordenação de Aperfeiçoamento de Pessoal de Nível Superior (CAPES). Ricardo V. is supported by Conselho Nacional de Desenvolvimento Científico e Tecnológico (CNPq). L.A. Romano and Luís A. Sampaio are research fellow of CNPq.

\section{RESUMO}

No presente estudo foi realizada uma análise ontogenética dos órgãos imunocompetentes do bijupirá até 
53 dia após a eclosão (dae) com técnicas histológica e imunohistoquímica. $\mathrm{O}$ rim foi o primeiro órgão linfohematopoiético a aparecer, ao 1 dae, seguido pelo baço aos 5 dae e pelo timo aos 7 dae. Os primeiros receptores $\mathrm{CD} 3 \mathrm{em}$ linfócitos foram observados em $27 \%$ no tecido do timo aos 7 dae e $99 \%$ aos 53 dae. A expressão fenotípica de receptores de $\mathrm{CD} 3$ foi registrada em $10 \%$ do rim aos 8 dae e em $32 \%$ aos 53 dae. Os receptores CD4 foram observados em $5 \%$ e $63 \%$ da área do timo aos 7 e 53 dae, respectivamente. No rim, linfócitos T4 foram primeiramente observados aos 13 dae em $9 \%$ do órgão e em $28 \%$ aos 53 dae, definindo o desenvolvimento funcional do sistema específico associado com a capacidade de memória imunológica.

Palavras-chave: bijupirá, sistema imune, ontogenia, imunohistoquímica, órgãos linfoides.

\section{REFERENCES}

BATISTA RC, FIGUEIREDO MA, ALMEIDA DV, ROMANO LA AND MARINS LF. 2014. Impairment of the immune system in $\mathrm{GH}$-overexpressing transgenic zebra fish (Daniorerio). Fish Shellfish Imm 36: 519 -524.

BENETTI DD ET AL. 2008. Advances in hatchery and grow-out technology of cobia Rachycentron canadum (Linnaeus). Aquacult Res 39: 701-711.

BOTHAM JW AND MANNING MJ. 1981. The histogenesis of the lymphoid organs in the carp Cyprinuscarpio L. and the ontogenetic development of allograft reactivity. J Fish Biol 19: 403-414.

BOWDEN TJ, COOK P AND ROMBOUT JH. 2005. Development and function of the thymus in teleosts. Fish Shellfish Imm 19: 413-427.

Chantanachookhin C, SeIKai T AND TANAKA M. 1991. Comparative study of the ontogeny of the lymphoid organs in three species of marine fish. Aquaculture 9: 143-155.

Chentoufi AA, PALumbo M And Polychronakos C. 2004. Proinsulin expression by Hassall's Corpuscles in the Mouse Thymus. Diabetes 53: 354-359.

CHILMONCZYK S. 1992. The Thymus in fish: development and possible function in the immune response. Annu Rev Fish Diseases 2: 181-200.

CHOU R, SU MS AND CHEN HY. 2001. Optimal dietary protein and lipid levels for juvenile cobia (Rachycentron canadum). Aquaculture. 193: 81-89.

CONRAD, M, DAVIS W AND KoOP B. 2007. TCR and CD3 Antibody Cross-Reactivity in 44 Species. Cytometry A 71: 925-933.

CRAIG SR, SchWARZ MH AND MCLEAN E. 2006. Juvenile cobia (Rachycentron canadum) can utilize a wide range of protein and lipid levels without impacts on production characteristics. Aquaculture 261: 384-391.
DANNEVING DH AND LANDSVERK T. 1995. Immunecomplex trapping in the splenic ellipsoids of rainbow trout (Oncorhynchus mykiss). Cell Tissue Res 282: 41-48.

ELlSAESSER CF, BLY JE AND CLEM LW. 1988. Phylogeny of lymphocyte heterogeneity the thymus of the channel catfish. Dev Comp Immunol 12: 787-799.

FISHELSON L.1995.Cytological and morphological ontogenesis and involution of the thymus in cichlid fishes (Cichlidae, Teleostei). J Morphol 223: 175-190.

GRACE MF AND MANNING MJ. 1980. Histogenesis of the lymphoid organs in rainbow trout, Salmo gairdneri. Rich. Dev Comp Immunol 4: 255-264.

Holt GJ, FAULK CK AND SCHWARZ MH. 2007. A review of the larviculture of cobia Rachycentron canadum, a warm water marine fish. Aquaculture 268: 181-187.

HSU S, RAINE L AND FANGER H. 1981. Use of AvidinBiotin-Peroxidase Complex $(\mathrm{ABC})$ in Immunoperoxidase Techniques: a comparison between $\mathrm{ABC}$ and unlabeled antibody (PAP) procedures. J Histochem Cytochem 29: 577-580.

JOSEFSSON S AND TATNER MF. 1993. Histogenesis of the lymphoid organs in sea bream (Sparus aurata L.). Fish Shellfish Immunol 3: 35-49.

LAing KJ, Zou JJ, Purcell M, Phillips R, SeCOMBes CJ AND HANSEN JD. 2006. Evolution of the CD4 family: teleost fish possess two divergent forms of CD4 in addition to lymphocyte activation gene-3. J Immunol 177: 39393951.

LAM SH, CHUA HL, GONG Z, WEN Z, LAM TJ AND SIN YM. 2002. Morphologic transformation of the thymus in developing zebrafish. Dev Dynamics 225: 87-94.

LiAO IC, HUANG TS, TSAI WS, HSUEH CM, CHANG SL AND LEAÑO EM. 2004. Cobia culture in Taiwan: current status and problems. Aquaculture 237:155-165.

LIAO IC AND LEAÑO EM. 2007. Cobia aquaculture: research, development and 747 commercial production. Taiwan: Asian Fisheries Society, 178 p.

LIU Y, ZHANG S, JIANG G, YANG D, LIAN J AND YANG Y. 2004. The development of the lymphoid organs of flounder, Paralichthys olivaceus, from hatching to 13 months. Fish Shellfish Immunol 16: 621-632.

Mishell RI AND DUTTON RW. 1967. Immunization of dissociated spleen cell cultures from normal mice. J Exp Med 126: 423-424.

Mulero I, Garcia-Ayala A, Meseguer J AND Mulero V. 2007.Maternal transfer of immunity and ontogeny of autologous immunocompetence of fish: a minireview. Aquaculture 268: 244-250.

NIELSEN ME AND ESTEVE-GASSENT MD. 2006. The eel immune system: present knowledge and the need for research. J FishDis 29: 65-78.

PADROS F AND CRESPO S. 1996. Ontogeny of the lymphoid organs in the turbot Scophthalmus maximus: a light and electron microscope study. Aquaculture 144: 1-16.

Palestro G, Novero D, Geuna M, Chiarle R, Chiusa L, PAGANO M AND PICH A. 1998. Role of the perivascular 
epithelium in the histogenesis of Hassall's Corpuscles: A Morphologic and immunohistological study. Inter J Surgical Pathol 6: 213-221.

PRESS CM AND EVENSEN O. 1999. The morphology of the immune system in teleost fishes. Fish Shellfish Immunol 9: 309-318.

RAZQUin BE, CASTillo A, LOPEZ-Fierro P, Álvarez F, ZAPATA A AND VILLENA AJ. 1990. Ontogeny of IgMproducing cells in the lymphoid organs of rainbow trout, Salmo gairdneri, Richardson: an immuno and enzymehistochemical study. J Fish Biol 36:159-173.

ROMANO LA, FERDER MD, STELLA IY, INSERRA F AND FERDER L. 1996. High correlation in renal tissue between computed image analysis and classical morphometric analysis. J. Histotechnol 19: 121-123.

ROMANO LA, MAROZZI V AND ZENOBI C. 2004.Utilizacion de anticuerpos humanos en la marcación de receptores CD3 y CD4 de linfocitos en Xiphophorushellerii. RevSoc Científica Argent 43: 123-127.
ROMBOUt JHW, HutTENHUIS HBT, PICCHIETTI S AND SCAPIGLIATI G. 2005. Phylogeny and ontogeny of fish leucocytes. Fish Shellfish Immunol 19: 441-455.

WATANABE N, WANG Y, LEE HK ITO T, WANG Y, CAO W AND LIU Y. 2005. Hassall's corpuscles instruct dendritic cells to induce CD4+ CD25+ regulatory T cells in human thymus. Nature 436: 1181-1185.

WEIBEL ER. 1979. Stereological methods In Practical methods for biological morphometry, vol. 1. London: AcademicPress.

WENTWORTH BM, RHODES C, SCHNETZLER B, GROSS DJ, HALBAN PA AND VILLA-KOMAROFF M. 1992. The ratio of mouse insulin I: insulin II does not reflect that of the corresponding preproinsulin mRNAs. Mol Cell Endocrinol 86: 177-186.

ZAPATA A, CHIBA A AND VARAS A. 1996. Cells and tissues of the immune system of Fish. In: The fish immune system: Organism pathogen and environment. G Iwama and T Nakanishi (Eds), Academic Press. New York. p. 1-62. 
